\title{
Life History and Seasonal Change in the Frequency of Dimorphic Stabilimenta of the Orb-web Spider, Octonoba sybotides (Uloboridae)
}

\author{
Takeshi Watanabe \\ Department of Zoology, Faculty of Science, Kyoto University, Kyoto, 606-8502, Japan \\ E-mail: takeshi@ecol.zool.kyoto-u.ac.jp
}

\begin{abstract}
The life history and reproductive activity of the Uloborid spider Octonoba sybotides were investigated. The seasonal change in the size distribution of the $O$. sybotides population at the study site showed that this spider has two generations per year: an overwintering generation and a summer generation. The overwintering generation hibernates from late November to early March as the juvenile stages. The duration of egg incubation varied greatly through the reproductive season, and seemed to be related to the total effective temperature. The number of eggs in each egg sac was significantly correlated with the weight of the mother. $O$. sybotides constructs a horizontal orb-web that frequently contains dimorphic stabilimenta (spiral and linear). The weights and condition indices of spiders showed that the spiders on webs with spiral stabilimenta to be in poorer energetic condition than spiders on webs with linear stabilimenta. The proportion of spiders on webs with spiral stabilimenta was negatively correlated with the prey abundance in their environment. The frequencies of spiral and linear stabilimenta in a population seem to be influenced by prey abundance, and prey-limited conditions induce the majority of $O$. sybotides to construct webs with spiral stabilimenta.
\end{abstract}

Key words - Life history, Octonoba sybotides, stabilimenta, orb-web, prey abundance, seasonal change

The spider genus Octonoba occurs in the southern part of Japan, southwestern China, and the United States (Opell 1979; Yoshida 1980, 1981). To date, 12 species have been described in Japan (Yoshida 1980, 1981). Octonoba sybotides (Bösenberg \& Strand 1906) is an uloborid spider that is widespread in eastern Asia. The function of the web design in $O$. sybotides has been documented (Watanabe 1999a, 1999b, 2000), but little is known concerning detail of the life history for the spider. Like many other uloborids, it constructs a horizontal orb-web with dimorphic stabilimenta in dimly lit sites at the base of trees, or between rocks, flowerpots, or piled logs (Watanabe 1999a). These habitats are patchily distributed, and the spider usually lays and guards the egg sac at the same site (Watanabe, personal observation). Nymphs hatching from the eggs disperse within a few days, although many remain near the hatching site and construct their webs among those of larger spiders. Therefore, $O$. sybotides at multiple stages can be observed within a small area. These ecological conditions enabled me to research the life history of $O$. sybotides. In this paper, I describe the life cycle and some aspects of the reproductive activity of $O$. sybotides based on observations in the field and laboratory.

Some orb-web spiders add a conspicuous silky structure, which is usually called a 'stabilimentum', to the surface of their webs. The designs of these stabilimenta are species-specific, but spiders show remarkable within-species variation in decorating behavior (Eberhard 1973; Lubin 1986; Nentwig \& Heimer 1987; Elgar et al. 1996; Blackledge 1998). In spite of much empirical knowledge, the factors that influence the 
facultative changes in decorating behavior have rarely been examined. Previous laboratory experiments have shown that the dimorphic stabilimentum form of $O$. sybotides changed in response to the internal energetic state of individual spiders (Watanabe 1999a). Food-deprived spiders tend to construct webs with spiral stabilimenta (SPwebs) and food-satiated spiders tend to construct webs with linear stabilimenta (LNwebs). Blackledge (1998) demonstrated that well-fed Argiope trifasciata included stabilimenta in their webs more often than hungrier spiders, and that both $A$. aurantia and $A$. trifasciata built larger stabilimenta when well fed. These facts suggest that the form of stabilimenta and their frequency of occurrence in the field change with prey abundance. To examine this hypothesis, I tested following two predictions on stabilimentum building by $O$. sybotides: (1) The proportion of webs with spiral stabilimenta will increase in prey-limited conditions in the field; (2) Spiders on webs with linear stabilimenta will be heavier than spiders on webs with spiral stabilimenta, because linear stabilimenta indicate that the owner spiders are more successful in prey capture than spiders on webs with spiral stabilimenta.

\section{Materials and methods}

\section{Life history}

Field observations were conducted at the Kyoto University Botanical Garden, in Kyoto basin, Japan, in 1998 and 1999 . A study area $(8 \times 1 \mathrm{~m})$ was established by placing 100 flowerpots on a wooden stand $(0.5 \mathrm{~m}$ high $)$ in 4 lines and 25 rows. Spiders constructed their webs and laid their egg sacs between the flowerpots, so I was able to collect all the spiders constructing webs between the flowerpots.

To obtain information on the life cycle of $\boldsymbol{O}$. sybotides, spiders were collected on the first or second of every month from March to November in 1999. All of the spiders constructing webs in the study area, except those holding egg sacs, were caught in separate plastic cases and their total body length and prosoma length were measured in the laboratory. After the measurements, all the spiders were returned to the study area.

Since the study site was checked almost every day, the days that eggs were laid were noted. The female $O$. sybotides modifies her prey-catching web by removing the spiral threads and reducing the number of radial threads, and constructs an egg sac at the center of the web. The female guards her egg sac for days, and rarely moves from the site (Watanabe, personal observation). In 1998, I mapped the sampling area (flowerpot array) and recorded the position of each egg sac on the map to monitor the survival of individual egg sacs. Although the spiders seemed to rarely move from their egg sac sites throughout the incubating period, the data for laying and hatching of unmarked egg sacs may be somewhat suspect. In 1999, for more precise monitoring, I labeled the edge of 36 egg sacs with non-toxic enamel paint. The spiders did not appear to react to the painting procedure or to the paint itself.

To examine the seasonal changes in duration of incubation in the field, 'rule of thermal summation' was applied to the development of eggs, referring the application of the same rule for the spiders' development by Li \& Jackson (1996). For a fixed temperature $(T)$, the thermal constant $(C)$ is expressed as:

where

$$
C=N\left(T-T_{0}\right)
$$

$N=$ number of days that the eggs take to hatch,

$T_{0}=$ threshold temperature of development.

$T-T_{0}=$ effective temperature. 
If the temperature fluctuates daily $\left(T_{i}\right)$, the formula may be rewritten as:

$$
\begin{aligned}
& C=\Sigma T_{i}-T_{0} N \\
& \Sigma T_{i}=T_{0} N+C
\end{aligned}
$$

Therefore, threshold temperature $\left(T_{0}\right)$ and thermal constant $(C)$ may be estimated by the linear regression model derived from the field data of $N$ and $T_{i}$, although this method produces only a crude estimate (Li \& Jackson, 1996).

\section{Egg production}

To examine the relationship between the food condition of the spider and its egg production, I collected mature female spiders from the botanical garden in early September 1998 and kept them in cylindrical cases that were $10 \mathrm{~cm}$ in diameter and $8 \mathrm{~cm}$ high. The top and bottom of each case were covered with a translucent plastic plate. A piece of wet cotton wool was placed on the bottom of the case to supply water. All of the spiders were kept in the laboratory at a constant temperature $\left(25^{\circ} \mathrm{C}\right)$. A total of 20 spiders laid eggs. I weighed the female spiders and their egg sacs. Then, I opened the egg sac and counted the number of eggs. I estimated the weight of each spider before oviposition as the total weight of the spider and its egg sac.

\section{Frequency of dimorphic stabilimenta}

I recorded the frequency of each type of silk decoration in the study area by counting all the spiders (total length $>3.0 \mathrm{~mm}$; including mature and immature spiders) with identifiable web types from early May to late September in 1999. Censuses were conducted on 8-11 days in each fortnight.

I estimated prey abundance in the study area by setting five artificial sticky traps in a linear array at $1.5 \mathrm{~m}$ intervals on the census days. The sticky traps were made of flexible plastic sheets, treated with Tanglefoot on both sides and stretched over hard black frames $(5 \times 10 \mathrm{~cm})$. Each trap was leaned against a flowerpot at a $45^{\circ}$ angle, though $O$. sybotides tends to construct horizontal webs. Since I aimed to detect the relative prey abundance for the spider, the angle of traps does not seem to affect the conclusion of this study. Although the spiders caught prey insects both during the day and at night, they appear to be diurnal foragers and catch prey insects mainly during the daytime (Watanabe, personal observation). The five traps were set at $1000 \mathrm{~h}$ and retrieved at $1700 \mathrm{~h}$, and the trapped insects were counted.

To evaluate energetic state of spiders, the weight of spiders collected from the study area were measured in the laboratory. Since the abdomen of spiders is elastic, a well-fed spider has a much rounder abdomen than a starved spider. I also measured the abdomen width and length and used the ratio as a condition index. The value of the condition index increases with the amount of prey digested. The sex of the spiders can be clearly determined when the prosoma length is over $0.80 \mathrm{~mm}$. Matured males tend to leave off constructing their webs (Watanabe, personal observation). Therefore, I only used the data for female spiders with a prosoma length exceeding $0.85 \mathrm{~mm}$.

\section{Results}

\section{Life cycle}

Webs of Octonoba sybotides that hibernated from the previous November appeared in early March (Fig. 1). Spiders grew during the spring and then began to lay eggs in May (Fig. 2). The number of large spiders decreased markedly by July, and smaller newly emerged nymphs dominated the study area. The new generation grew during the 


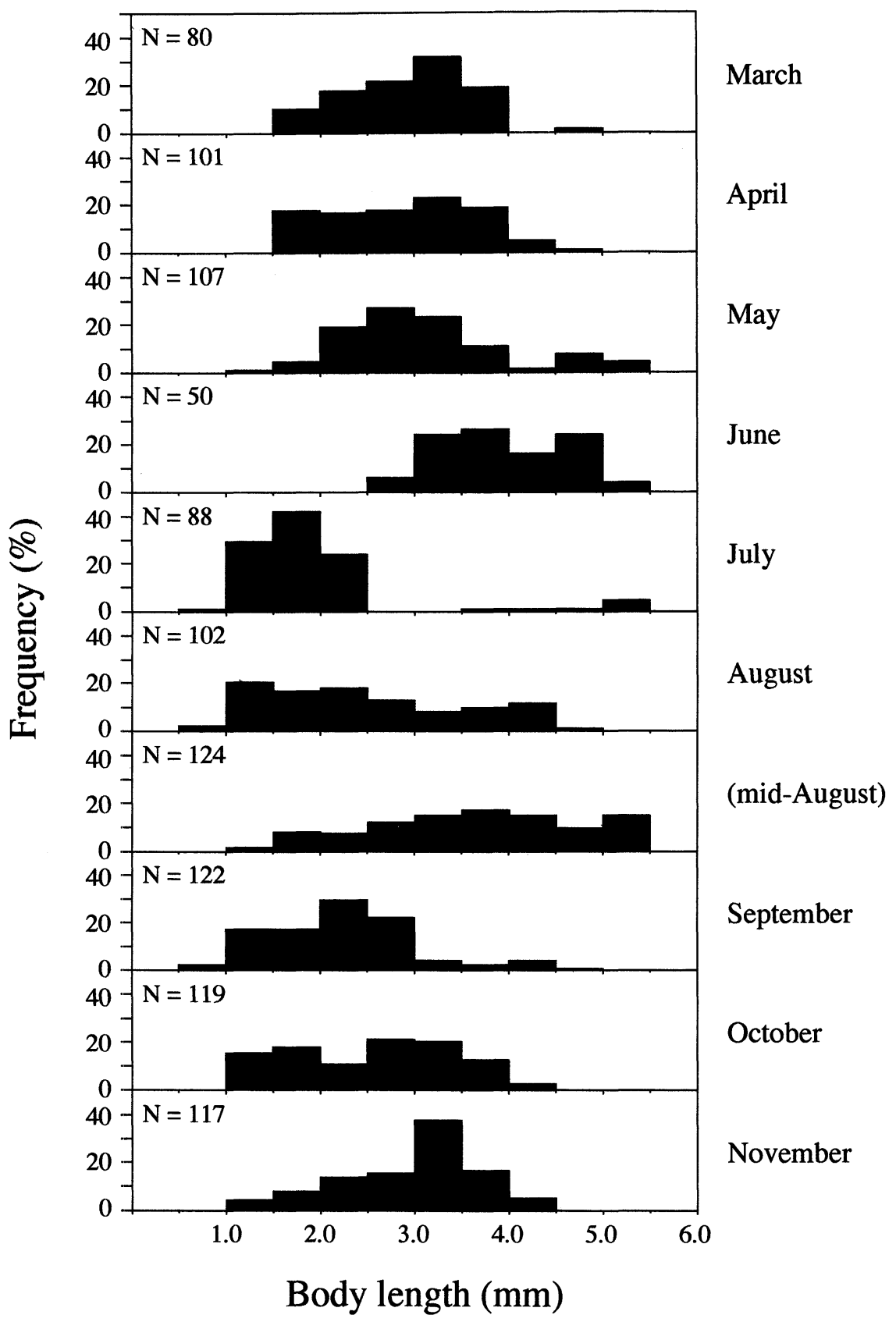

Fig. 1. Size distribution throughout the 1999 season. $N$ is the number of spiders measured. Surveys were conducted on the 1 st or 2 nd day of each month, except March (3rd, 4th and 5th) and mid-August (16th). 
summer and began to lay eggs in August (Figs. 1-2). The adult spiders disappeared by the beginning of September and were replaced by the smaller nymphs. The webs of immature $O$. sybotides disappeared by mid November.

\section{Duration of incubation}

Only 15 of the marked egg sacs hatched; the others died before hatching. The number of days until hatching varied greatly through the breeding season (Fig. 3). The eggs took longer to hatch earlier in the year, hatched more quickly towards mid summer,

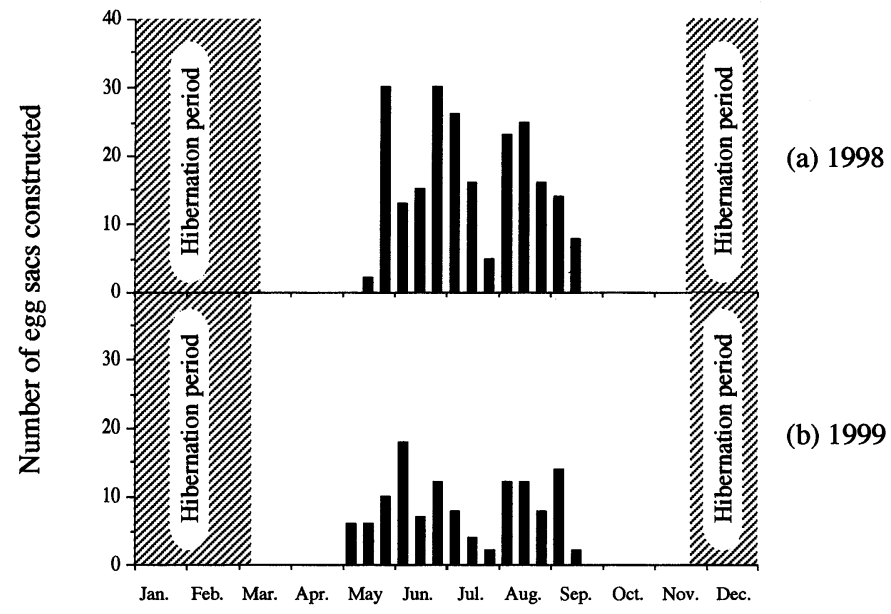

Fig. 2. Seasonal change in the number of egg sacs present in the study area.

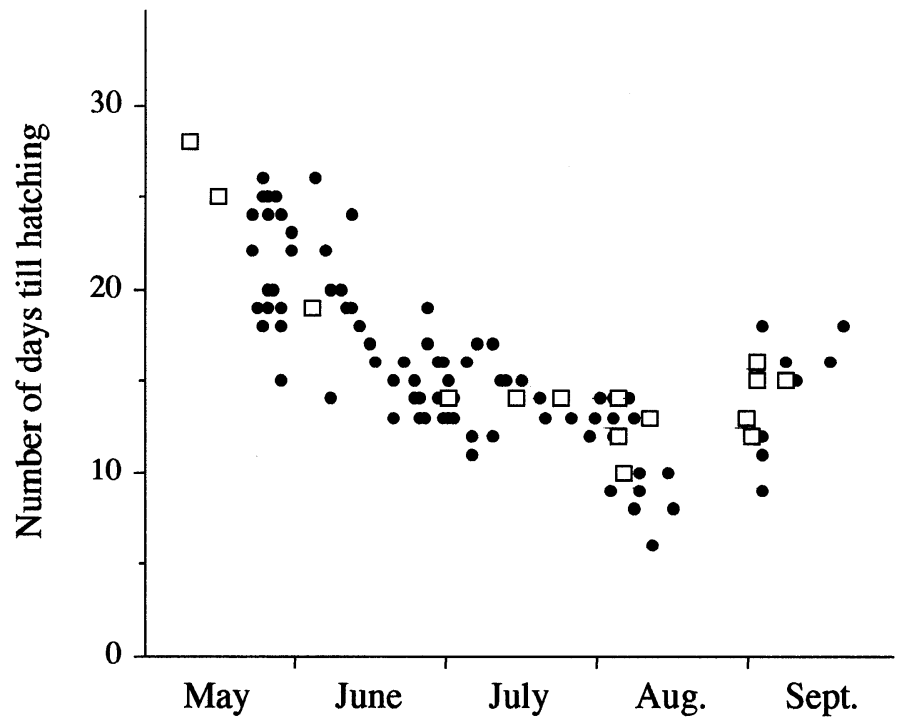

Egg laying days

Fig. 3. The relationship between the date of egg laying and the duration of incubation for marked (open squares) and unmarked (solid circles) egg sacs. 


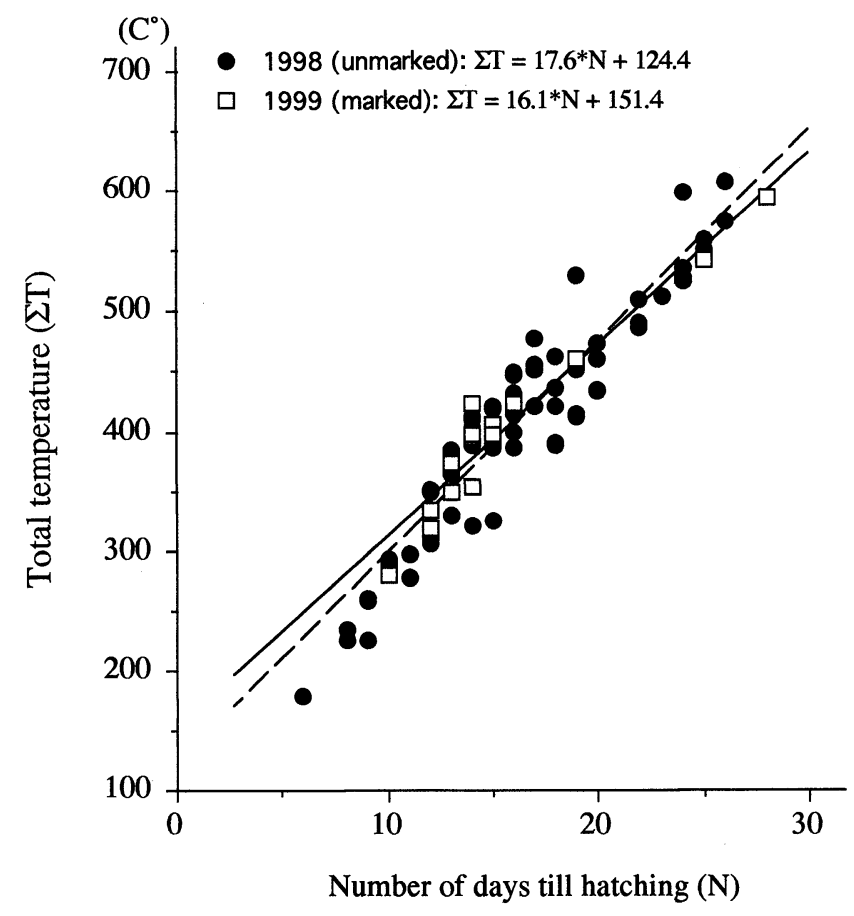

Fig. 4. The relationship between the total temperature and the duration of incubation for each marked (open squares) and unmarked (solid circles) egg sacs.

and then again took longer to hatch in September.

Figure 4 shows the relationship between the observed number of days until hatching for each egg sac (marked and unmarked) and the total mean temperature. I used the daily mean temperature data recorded at the Experimental Nursery of the Faculty of Agriculture, which is located in just northwest of the study area. The regression lines were significant for the data for both marked and unmarked spiders. The lines are fit by the linear models $y=151.4+16.1 x\left(r^{2}=0.935, p<0.001\right)$ and $y=124.4+17.6 x\left(r^{2}=\right.$ $0.878, p<0.001)$, respectively. The slopes of the two lines are not significantly different $\left(F_{1,103}=0.745, p>0.3\right)$, and the total temperatures for the marked and unmarked spiders were not significantly different (ANCOVA; $F_{1,104}=0.241, p>0.6$ ). Adding the daily effective temperatures retroactively from the day of laying until hatching the sums were 151.4 degree-days (marked) and 124.4 degree-days (unmarked). The threshold temperature was estimated to be $16.1^{\circ} \mathrm{C}$ (marked) and $17.6^{\circ} \mathrm{C}$ (unmarked).

\section{Clutch size}

Figure 5 shows the significant relationship between the number of eggs in each egg sac and the weight of the guarding spider $\left(r^{2}=0.471, p<0.01\right)$. The relationship between the clutch size and the estimated weight of spiders before egg laying was significant $\left(r^{2}=0.902, p<0.001\right)$.

Prey abundance and frequency of dimorphic stabilimenta

The number of flying insects captured by the artificial traps was relatively high in 

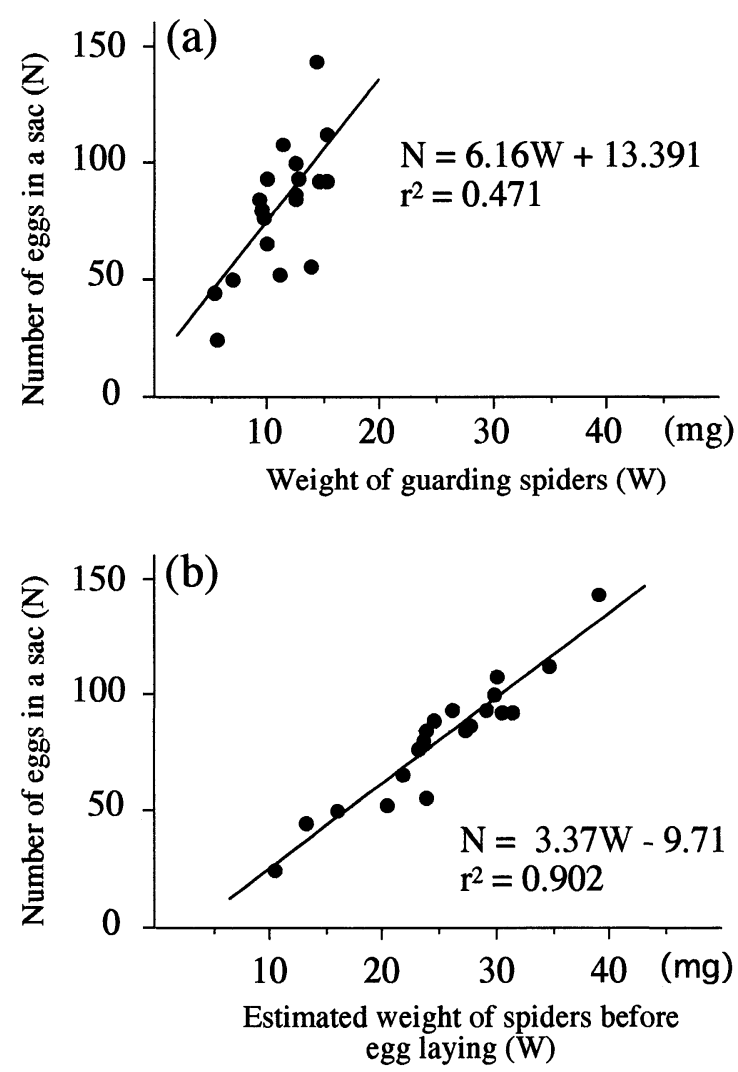

Fig. 5. The relationship between the weight of the brood-guarding spider (a) and the number of eggs in the guarded sac (data from 20 female spiders). The horizontal bar in (b) indicates the estimated weight of the guarding spiders before egg laying: ( $W=$ weight of egg sac + weight of guarding spider).

May and June, but decreased in August and September (Fig. 6). A large proportion of the webs had linear stabilimenta $(>55 \%)$ in May and June, but webs with spiral stabilimenta predominated ( $>50 \%$ ) in August and September (Fig. 7). The average proportion of webs with spiral stabilimenta (SP-webs) in each two-week period was negatively correlated with the average number of flying insects captured by the traps in the same period (Kendall rank correlation test: $\tau=-0.722, Z=-2.711, p<0.01$ ) (Fig. $8)$.

From the observation of seasonal change in size distributions, spiders collected on early May and June seemed to be of overwintering generation, and those collected on early August and mid-August seemed to be of summer generation. Using data of these spiders, I compared the body weight and condition indices of spiders with distinction of generations and web types (SP- or LN-web).

Weight of spiders was significantly different between web-types (two-way factorial ANCOVA: $\left.F_{1,140}=61.340, p<0.0001\right)$ but not between generations $\left(F_{1,140}=0.007, p>\right.$ 0.9) (Fig. 9). The spiders on the $\mathrm{LN}$-webs were significantly heavier than those on the SP-webs. 


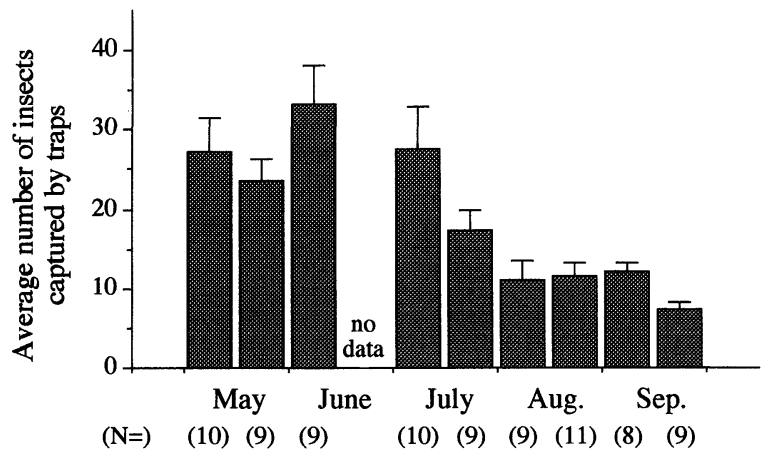

Fig. 6. The number of flying insects captured by artificial traps. Data collected during each fortnight were averaged. Each bar shows the standard deviation. The numbers in parentheses indicate the number of sampling days during each period.

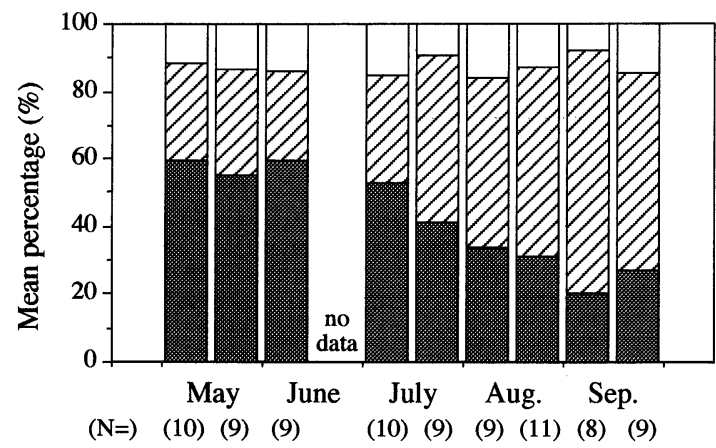

Fig. 7. Seasonal changes in the percentage of webs with linear (dark), spiral (crosshatched), and no stabilimenta (open). Data collected during each fortnight were averaged. The numbers in parentheses indicate the number of observation days during the fortnight. The total number of webs in the study area ranged from 19 to 77 on 84 observation days.

The condition indices of spiders in each group were not significantly correlated with prosoma length, respectively, and condition index was significantly different between web-types (two-way factorial ANOVA: $F_{1,140}=81.574, p<0.001$ ) but not between generations $\left(F_{1,140}=0.001, p>0.7\right)$ (Fig. 10). The spiders on the LN-webs were fatter than the spiders on the SP-webs.

\section{Discussion}

The Octonoba sybotides studied appears to be bivoltine, with an overwintering generation and a summer generation (Fig. 11). The hatchlings of the summer generation grow rapidly, mature by late August, and deposit the egg sacs. The hatchlings from these sacs overwinter in the nymphal stages and mature in late spring in the next year. The large variation in the size of the spiders indicated that spiders do not begin to hibernate at a particular growth stage. It has been suggested that spiders change their life cycle in response to different climatic conditions (Toft 1983; Wise 1984). The life 


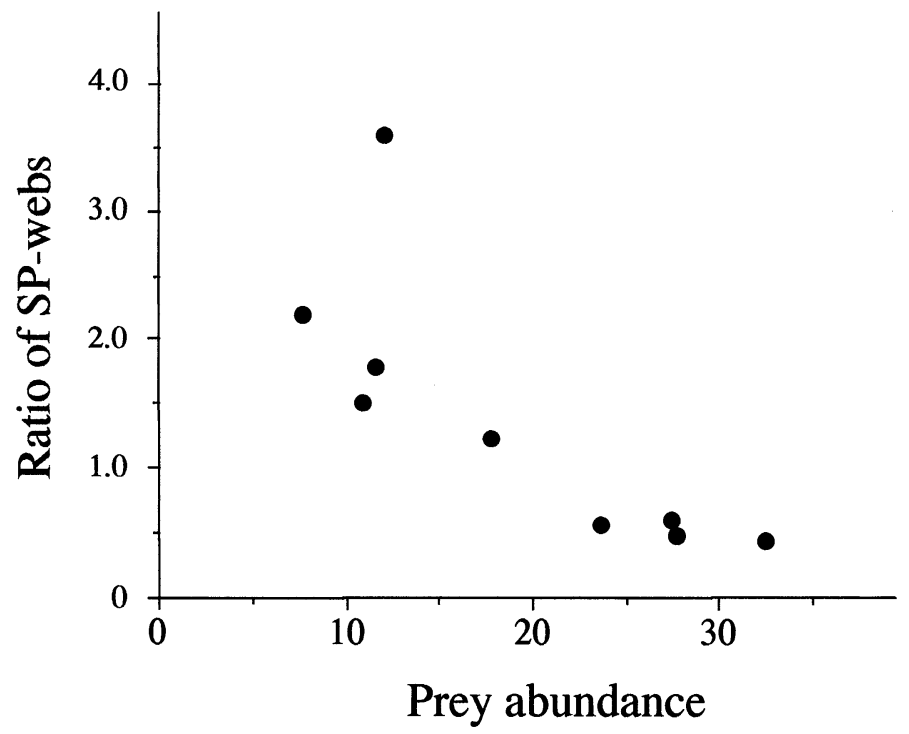

Fig. 8. Relationship between prey abundance and the ratio of the number of SP-webs to LN-webs. Each point is the average of two fortnightly values.

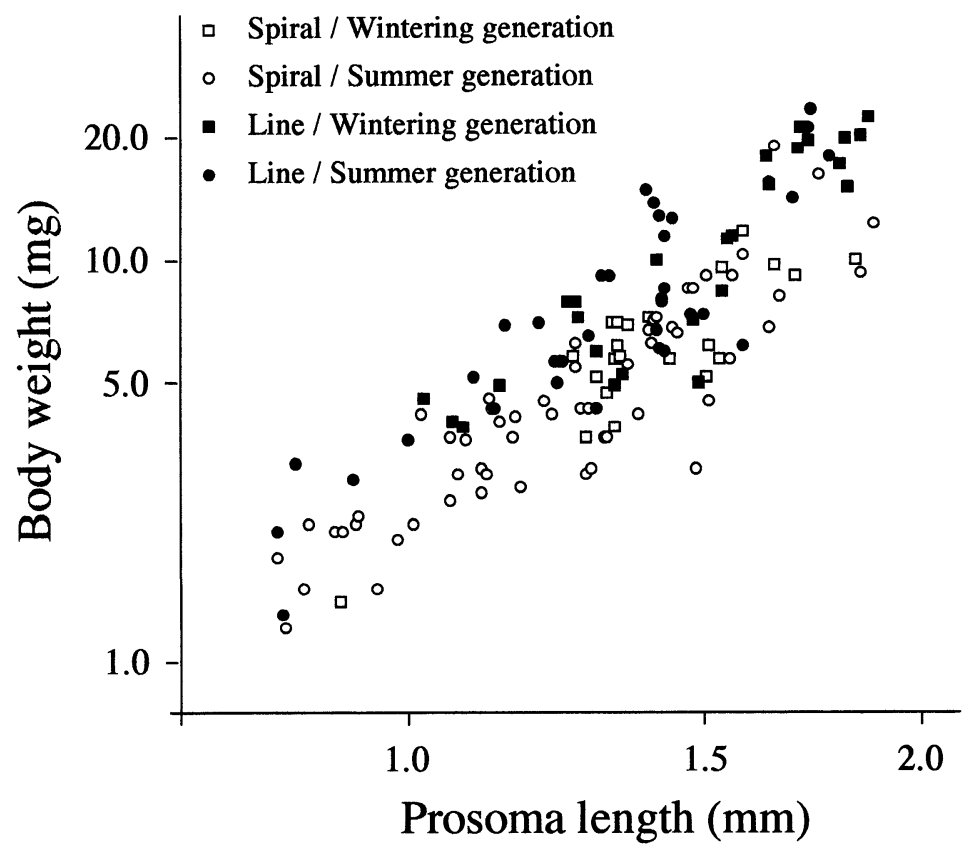

Fig. 9. Relationship between the prosoma length $(\mathrm{mm})$ and body weight $(\mathrm{mg})$. Open squares: overwintering generation spiders on SP-webs $(N=23)$; Open circles: summer generation spider on SP-webs $(N=58)$; Solid squares: overwintering generation spider on LN-webs $(N=27)$; Solid circles: summer generation spiders on $\mathrm{LN}$-webs $(N=36)$. 


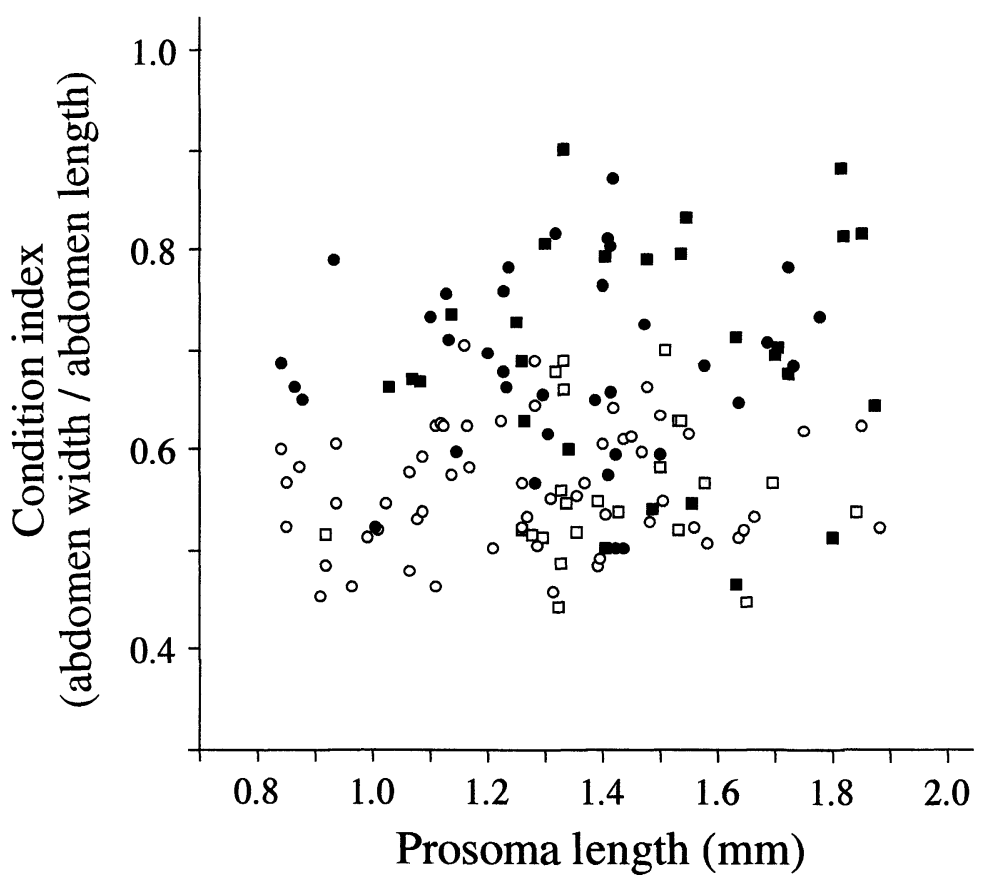

Fig. 10. Condition indices of spiders. Open squares: overwintering generation spiders on SP-webs $(N=23)$; Open circles: summer generation spider on SP-webs $(N=58)$; Solid squares: overwintering generation spider on LN-webs $(N=27)$; Solid circles: summer generation spiders on LN-webs $(N=36)$.

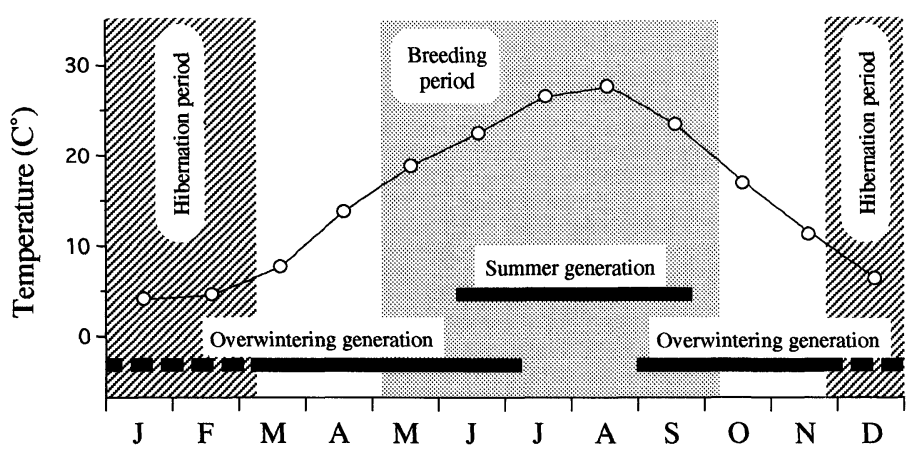

Fig. 11. Schematic diagram of the life cycle of $O$. sybotides at the study site. Open circles represent monthly mean temperature (average year).

history of spiders is influenced by the rate of growth and the timing of maturation, and the growth of a spider is greatly influenced by food intake and temperature (Schaefer 1976; Vollrath 1987). Although this study did not clarify the effect of temperature on the growth of the spiders, the results suggest that temperature sets an important limit on the timing of reproduction. The total effective temperature seems to determine the 
optimal period for the reproductive activity of $O$. sybotides. A threshold temperature appears to determine the start of the reproduction period and the overwintering generation begins to lay eggs as soon as the temperature exceeds this threshold temperature. On the other hand, a declining temperature produces a different response, restricting the reproductive activity in September. Spiders appear to stop their reproductive activities at temperatures that are still higher than the threshold temperature, in order to obtain the total effective temperature necessary for development of the eggs.

The clutch sizes are positively correlated with the weight of the female of $O$. sybotides. Since the weight is correlated with the amount of prey digested, it is likely that prey capture success of $O$. sybotides is faithfully reflected in egg output. However, $O$. sybotides seems to be semelparous (Watanabe, personal observation). Therefore, the fitness of the spider must be determined from the total number of offspring that each spider produces during its life. Previous experiments with these spiders suggest that a change in the feeding rate influences the timing of egg production; oviposition occurred most often with food-deprived spiders (Watanabe 1999a). A large variation in the number of eggs laid at a given time might be part of the strategy of sequential reproduction by individual spiders in a fluctuating prey environment. The relationship between the timing of egg production and the feeding history of spiders requires further study.

This study also demonstrated that a large proportion of spiders add linear stabilimenta to their webs when prey insects are abundant, whereas the majority adds spiral stabilimenta when prey insects are limited. Comparing the body weight and fatness of spiders on the distinct stabilimentum forms, spiders on the $\mathrm{LN}$-webs seemed to be in better energetic condition than spiders on SP-webs. A previous study found that the prey capture rates of both the SP- and LN-webs were positively correlated with the number of insects captured in the traps (Watanabe, in preparation). Therefore, the frequencies of dimorphic stabilimenta seem to change in response to prey capture success, which is tightly related to prey abundance, and a large proportion of spiders tend to construct SP-webs when prey insects are limited.

This study considered population differences in the stabilimentum patterns in the field. Combined with previous results (Watanabe 1999a), it is very likely that the frequencies of each type of stabilimentum indicate the prey abundance in a habitat. Seasonal differences in prey abundance can be applied to spatial differences. In the same season, it is predicted that in a prey-limited habitat a greater proportion of $O$. sybotides will construct SP-webs, whereas $\mathrm{LN}$-webs will predominate in prey-rich habitats. Geographic comparative studies, which compare the abundance of prey insects and the proportions of stabilimentum types in local areas, should provide further support for this hypothesis on the cause of population differences in the occurrence of dimorphic stabilimenta.

\section{Acknowledgments}

I thank M. Yoshida and T. Sota for their comments on earlier drafts of this manuscript. Thanks are also extended to anonymous referees for their suggestions.

\section{References}

Blackledge, T. A. 1998. Stabilimentum variation and foraging success in Argiope aurantia and Argiope trifasciata (Araneae: Araneidae). J. Zool. London, 246: 21-27.

Eberhard, W. G. 1973. Stabilimenta on the webs of Uloborus diversus (Araneae: Uloboridae) and other spiders. J. Zool. London, 171: 367-384. 
Elgar, M. A., Allan, R. A. \& Evans, T. A. 1996. Foraging strategies in orb-spinning spiders: Ambient light and silk decorations in Argiope aetherea Walckenaer (Araneae: Araneoidea). Aust. J. Ecol., 21: 464-467.

Li, D \& Jackson, R. R. 1996. How temperature affects development and reproduction in spiders: a review. J. Thermal Biol., 21: 245-274.

Lubin, Y. D. 1986. Web building and prey capture in the Uloboridae. pp. 132-171. In: Shear, W. A. (ed.) Spiders: Webs, Behabior, and Evolution. Stanford University Press. Stanford, California.

Nentwig, W. \& Heimer, S. 1987. Ecological aspects of spider webs. pp. 211-228. In: Nentwig, W. (ed.) Ecophysiology of Spiders. Springer, Berlin.

Opell, B. D. 1979. Revision of the genera and tropical American species of the family Uloboridae. Bull. Mus. Comp. Zool., 148: 443-549.

Schaefer, M. 1976. Experimentelle Untersuchungen zum Jahreszyklus und zur Uberwinterung von Spinnen (Araneidae). Zool. Jb. Syst., 103: 127.

Toft, S. 1983. Life cycles of Meta segmentata (Clerck, 1757) and Meta mengei (Blackwall, 1869) in western europe (Arachnida: Araneae: Tetragnathidae). Verh. Naturwiss. Ver. Hamburg, 26: 265276.

Vollrath, F. 1987. Growth, foraging and reproductive success. pp. 357-370. In: Ecophisiology of Spiders. Nentwig, W. (ed.). Springer Verlag, Berlin.

Watanabe, T. 1999a. The influence of energetic state on the form of stabilimentum built by Octonoba sybotides (Araneae: Uloboridae). Ethology, 105: 719-725.

Watanabe, T. 1999b. Prey-attraction as a possible function of the silk decoration of the Uloborid spider Octonoba sybotides. Behav. Ecol., 10: 607-611.

Watanabe, T. 2000. Web tuning of an orb-web spider, Octonoba sybotides, regulates prey-catching behaviour. Proc. R. Soc. Lond. B, 267: 565-569.

Wise, D. H. 1984. Phenology and life history of the filmy dome spider (Neriene radiata) (Araneae: Linyphiidae) in 2 local Maryland (USA) populations. Psyche, 91: 267-288.

Yoshida, H. 1980. Six Japanese species of the genera Octonoba and Philoponella (Araneae: Uloboridae). Acta Arachnol., 29: 57-64.

Yoshida, H. 1981. 7 new species of the genus Octonoba (Araneae: Uloboridae) from the Ryukyus, Japan. Acta Arachnol., 30: 21-32.

(Received January 15, 2000/Accepted April 3, 2000) 


\section{Acta Arachnologica, Vol. 49, No. 1 掲載論文の和文要旨}

カタハリウズグモの生活史および隠れ帯二型の 出現頻度の季節変化 (pp. 1-12)

渡部 健( T606-8502 京都市左京区北白川追分 町, 京都大学大学院理学研究科生物科学専攻動 物生態学研究室)

京都大学理学部付属植物園内に生息するカ夕 ハリウズグモの生活史および，円網の隠れ帯二 型（直線型・ウズ型）の出現頻度の季節変化を 調查した. 調查地内のカタハリウズグモは二化 性で，夏世代と越冬世代をもっていた，産卵か ら幼体が出現するまでの時間は繁殖期間中に変 化した。おそらく, 卵発生における有効積算温 度の効果によるものと推測された．卵囊中の卵 数は, 保護している雌親の体重, および推定さ れる産卵前の雌親の体重と高い正の相関関係を 示した. 隠れ帯二型の出現頻度は季節変化し, 初夏には直線型が多く，秋に向けてウズ型の頻 度が増大する傾向を示した，直線帯をつけた網 の個体は，ウズ帯をつけた網の個体に較べ，体 重が重く，腹部の膨らみ度合が大きかったこと から，隠れ帯二型は，個体の栄養状態に対応し ていることが示唆された. 初夏から秋に向けて 餌となる飛翔昆虫量が減少することが, 隠れ帯 二型の出現頻度の季節変化に影響を与えている と推察した。

台湾産 Nesticella 属(クモ目：ホラヒメグモ科) の 1 新種（pp. 13-16)

卓 逸民 ${ }^{1}$, 吉田 哉 ${ }^{2}{ }^{1}$ 中華民國臺灣省臺中市中 港路三段 181 號, 東海大學生物系 ; ${ }^{2}$ T990-2484 山形市篭田 2 丁目 7 番 16 号)

台湾産ホラヒメグモ科 Nesticella Lehtinen \& Saaristo1980 属の 1 新種を記載した.この属は アジアからアフリカの熱帯地方に多く分布す る. 東アジアからは, Nesticella quelpartensis (Paik \& Namkung 1969), N. brevipes (Yaginuma 1970), N. mogera (Yaginuma 1972), N. okinawaensis (Yaginuma 1979), N. odonta (Chen 1984）および N. yui Wunderlich \& Song 1994 の
6 種がこれまで記録されている（Platnick 1997; Song et al. 1999). 今回記載した種はこの地域か らの 7 種目にあたる.

日本産 Eriophora 属のクモ類（クモ目：コガネ グモ科)（pp. 17-28）

谷川明男 (†248-0025 神奈川県鎌倉市七里ガ浜 東 2-3-1 神奈川県立七里ガ浜高等学校)

分岐分析に基づいて, これまで Zilla 属に置 かれていた日本産の 3 種のクモ類を Eriophora 属に移し, 再記載し図示した。また, 沖縄島産 Eriophora 属の 1 新種を記載した. 本論文であつ かったクモ類は, Eriophora sagana (Bösenberg \& Strand 1906) comb. nov. サガオニグモ, $E$. sachalinensis (S. Saito 1934) comb. nov. カラフ トオニグモ, E. sachalinensis (S. Saito 1934) comb. nov. キンカタハリオニグモおよびE. yanbaruensis sp. nov. ヤンバルオニグモ（新称） の 4 種である. Aranea sagana Bösenberg \& Strand 1906 を Aranea sagana (Keyserling 1893) の新参ホモニムから復活させ, Eriophora migra Zhu \& Song 1994は Eriophora sagana (Bösenberg \& Strand 1906) comb. nov. サガオニグモの, Eriophora flava Zhu \& Song 1994 は Eriophora sachalinensis (S. Saito 1934) comb. nov. カラフ トオニグモの新参シノニムとした.

\section{沖縄島から採集された無眼の真洞穴性ヤチグモ} 属の 1 新種 (pp. 29-40)

下謝名松榮 ${ }^{1}$-西平守孝 ${ }^{2}$ ( ${ }^{1}$ T903-0129 沖縄県西 原町子原 1 , 琉球大学教育学部理科教育; ${ }^{2}$ 个 980-8587 仙台市青葉区荒巻字青葉, 東北大学大 学院理学研究科生物学専攻)

沖縄本島の石灰洞から見つかった小型の洞穴 性ヤチグモを Coelotes troglocaecus n. sp. (オキ ナワホラアナヤチグモ）として記載した.ヤチ グモでは国内初の無眼種である。同所的に生息 する Coelotes okinawensis Shimojana 1989 オキ ナワヤチグモと比較しつつ形態記載をおこなっ 